\title{
Analyzing the Factors Influencing Students' Fluency in English Speaking Skills: A Case in Bina Nusantara University
}

\author{
Marisca Revani Putri ${ }^{1}$, Venansia Ajeng Surya Ariyani Pedo ${ }^{2}$, Norma Pawestri ${ }^{3}$ \\ \{mrputri@binus.edu, venansia.surya@binus.ac.id, norma.pawestri@binus.ac.id\} \\ ${ }^{1}$ Language Center, Hotel Management Department, Faculty of Humanities, Bina Nusantara \\ University, Jakarta, Indonesia 11480 \\ ${ }^{2}$ Language Center, English Department, Faculty of Humanities, Bina Nusantara University, \\ Jakarta, Indonesia 11480 \\ ${ }^{3}$ Language Center, International Relation Department, Faculty of Humanities, Bina \\ Nusantara University, Jakarta, Indonesia 11480
}

\begin{abstract}
The needs of the English language had been changed along with the increased demand of graduates in facing the Industry 4.0 which also implied that speaking skills became the key for the graduates to communicate with people from various backgrounds. This research aimed to investigate the factors influencing the speaking fluency of the students in English in Focus course to find out the proper teaching-learning method in speaking session. The case-study method was implemented to conclude this research. The participants of this study were 127 students majoring in Information System \& Management Program, Accountancy Program, Japanese Department, and International Relation Department who registered in English in Focus Course in the odd semester, 2018/2019 academic year. The data were gathered through equestionnaire, depth analysis on students' speaking recording tasks, and document analysis. The result showed nine factors were affecting the speaking fluency in English.
\end{abstract}

Keywords: Need Analysis, Speaking Fluency, Factors Influencing Fluency, ELT.

\section{INTRODUCTION}

English speaking skills have become one of the requirements in getting a job in this global era. Graduates should master certain English proficiency levels when they applied for a job and in the interview process, they were required to speak English fluently. While the fact that English speaking skills still become a challenge as well as problems for graduates to be mastered. The demand for English-speaking skills increased along with the development of industrial revolution 4.0 that required the graduates not only able to speak in English but use it meaningfully. Thus, fluency becomes inevitably crucial to be developed while the students learn English speaking skills and fluency put more attention to the meaningful communication development as noted in fluency-oriented approach [1].

There were nine factors affecting English speaking fluency, namely linguistic factors, psycholinguistics factors, age, sociolinguistic factors, bilingualism, individual differences or 
personality, developmental factors, the frequency of the input, and exposure [2][3][4]. Along with the demand for rapid technology development in industrial revolution 4.0, research also emphasized research on the importance of developing students' speaking skills in the classroom [1]. Since English is a foreign language in Indonesia, lecturers faced many challenges in teaching English speaking skills. The students in Indonesia are typically "shy" to speak English in a public area and they are also afraid of making a mistake. This situation made the students have limited exposure and the opportunity to use their English-speaking skills. Previous research found that lecturers should frequently provide fluency activities for successful language learning, especially when English is regarded as a foreign language [5]. The importance of speaking fluency in establishing communication in the EFL classroom was also emphasized in the finding of a research result [6]. This research found that fluency also brought advantages in improving the quality of speaking in a real-life context.

Along with the other researches, fluency plays a crucial role in achieving the purpose of communication in conversation [2]. The previous research findings showed that the classroom becomes the main place and source where the students can practice their English-speaking fluency in the EFL context. Thus, this research aimed to find out in what extent the factors affecting the students' English speaking fluency in English in Focus course so that the lecturer could develop suitable learning materials as well as the appropriate teaching methods in developing students' English speaking fluency in the classroom.

\section{METHOD}

The case study method was employed to achieve the result and conclusion of this study. Case study method defined as a detailed analysis in examining "how" a single event can be established. The data of this study were gathered from 127 students from Information System \& Management Program, Accountancy Program, Japanese Department, and International Relation Department. The students were registered in English in Focus Course in the odd semester, 2018/2019 academic year. Data resource triangulation was employed to ensure the validity of this research.

The data for this research were gathered through e-questionnaire from the students, recordings of students speaking tasks, and document analysis on students' speaking learning results. The e-questionnaire was be delivered to students from Information System \& Management Program, Accountancy Program, Japanese Department, and International Relation Department, who registered in English in Focus Course in the odd semester, 2018/2019 academic year. Google Form was used as the platform of the e-questionnaire. Eighteen questions were asked on the e-questionnaire. The questions in the e-questionnaire were about the student's backgrounds, culture, duration of their English learning, number of mastered languages, as well as their attitude in learning English. There were 12 open-ended questions and 6 close-ended questions in the e-questionnaire. 127 students answered the questions from a total of 180 students in the registered classes. The depth analysis was done to 127 student's speaking recording tasks. The analyses were based on a rubric. The rubric was constructed based on the theories in chapter two of this article, especially the theories from Kumar [1] about speaking fluency. The rubric saw the two aspects of speaking fluency, namely meaningful communication and the least amount of correction on the error made by the students. The student's speaking learning results were also analyzed to see the improvement of their learning. The students speaking results were in the form of a portfolio and consisted of the student's learning record. 
Those three instruments were analyzed and compared to answer the research questions. The first research questions: What are the factors influencing English speaking fluency of the students in English in Focus Course? and the second research question: To what extent do the factors influence English speaking fluency of the students in English in Focus Course? were answered by comparing the result of the e-questionnaire with the result of the student's recording depth analysis. While the third research question: What is the suitable method to develop English speaking fluency of the students in English in Focus Course? was answered by analyzing the answer to research question $1 \& 2$ with the student's speaking learning result.

\section{RESULT AND DISCUSSION}

By answering the first and second research questions, the finding showed that the nine factors affecting the speaking fluency were related to each other. Following were the explanation of each factor affecting the student's fluency in English in Focus Course.

The order of the nine factors that most affecting factors was started from linguistics factors like the number one factor that affecting student's speaking fluency in English in Focus course. The second factor was the sociolinguistics factor. It was followed by the bilingualism factor, exposure factor, frequency of input factor, developmental factor, age factor, psycholinguistic factor, and individual differences or personality factors. The order was shown in figure 1 below:

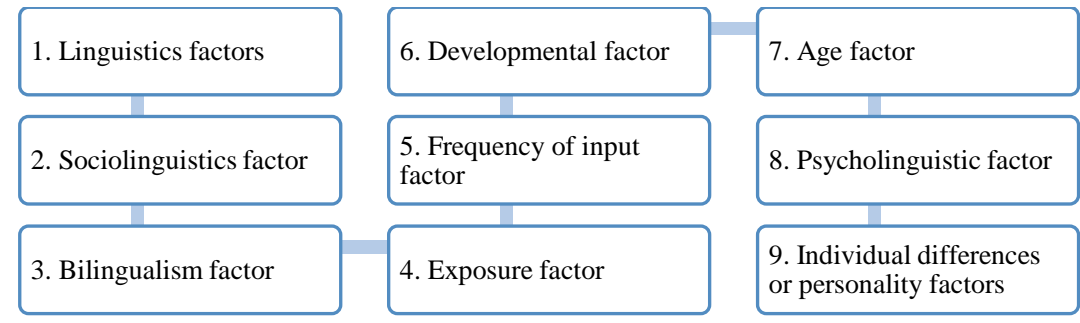

Fig. 1. The order of the factors affecting student's speaking fluency in English in Focus Course

The result of speaking task analysis showed that the students had issues in linguistic factors. The linguistic elements that dominantly affected the students were phonetic, phonology, and grammar.
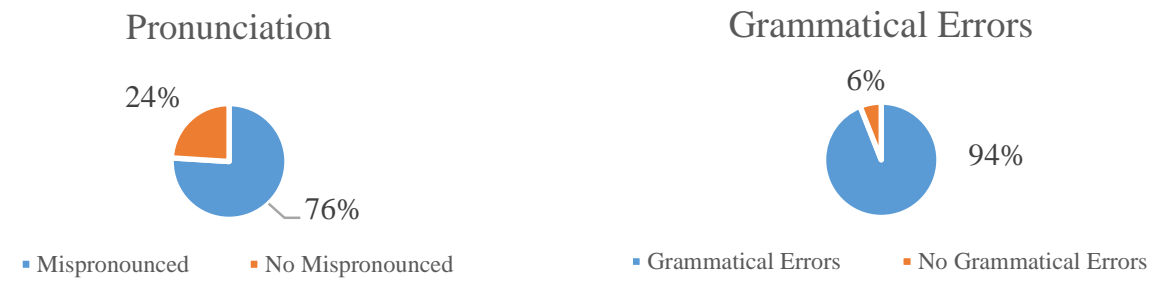

Fig. 2. Linguistic factors affecting student's speaking skills in English in Focus Course

Figure 2 showed that $76 \%$ of the students produce mispronounced pronunciation on their speaking task and $94 \%$ of the students made grammatical errors during their speaking test. These findings resulted from the low exposure in speaking English as resulted in the questionnaire result. The result showed that only $1.72 \%$ students whom always spoke English 
in a week. Then, 25\% students were often speaking English in a week. There were $41 \%$ students sometimes utilize English in their conversation in a week, and $31 \%$ of the students were rarely speaking in English in a week. The last finding showed that only $0.86 \%$ whom never used English in a week. Based on the result, the students had limited exposure to speak English. Further, the questionnaire results also found that the students spoke English when they were on campus and when they were in English class. Besides, the result also found that the students were also exposed to English when they were playing online games. Input and exposure the students gained from online games were passive English where the students could not produce their speaking actively. Thus, the students had problems with their pronunciation since they had more passive exposure than active exposure to speak and utilized English in the real context.

The people around the students also played a role in the frequency of input to the students. The research found that only $12.93 \%$ of people around them who often spoke in English while the other $51.72 \%$ of students were occasionally speaking in English. Exposure and frequency of input played a crucial role in the language development of the students. The result found that $72.4 \%$ of students had already had English course when they were still in elementary school. In time, sociolinguistics and bilingualism factors played their role in affecting the student's speaking fluency. The students had limited exposure to speak in English with the people around them. Besides, the position of English as a foreign language also impacted the use of English in the environment around the students. Though the students had an English course since they were in elementary school, they rarely spoke English with the people around them.

However, the findings showed the psycholinguistics factors did not become a major problem for the students since the result shows that $50 \%$ of the students were produce deviated sentences. These results were related to the student's personality factors that found $70 \%$ of the students were 19 years-old while the others were on the age range between 17-21 years-old. These findings indicated that the students were the digital native generation who did not have problems accessing information through the internet and other information resources. On the other hand, the students felt reluctant and personally shy to make a mistake when it came to speak in English. The result also found that $57 \%$ of the students came from outside Jakarta and $27 \%$ came from outside Java island which commonly spoke in their mother tongue rather than English.

Answering the third research question, the findings in student's learning preferences will give an initial result, as shown in figure 3 below:

\section{Learning Preferences}

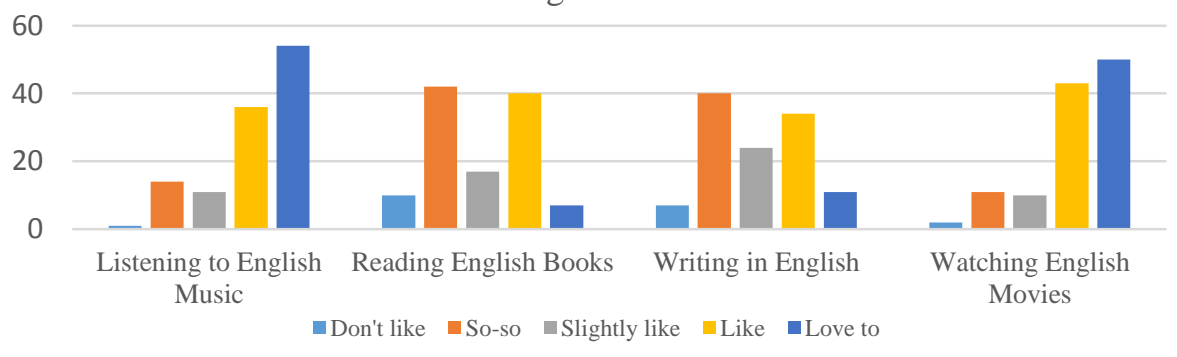

Fig. 3. Student's Learning Preferences 
The student's learning preferences were varied and covered all VAK learning styles, namely visual, auditory, and kinesthetic. The result in figure 3 showed that the students tended to have more interest in listening to music and watching movies. Thus, in designing the teaching method and teaching materials, the lecturer should provide more activities that may attract the student's attention and motivation that closely related to their life. It also revealed that the learning activities should use more audio and visual activities to engage the student's attention and motivation. For example, the materials could be short movies or part of a song's lyrics that may encourage the students to explore more and have more exposure when they have to utilize English in expressing their ideas.

Based on the speaking task analysis result, the students had issues in pronunciation and grammar as shown in figure 2 above. Still, the students had good production in producing meaningful communication as shown in figure 4 below:

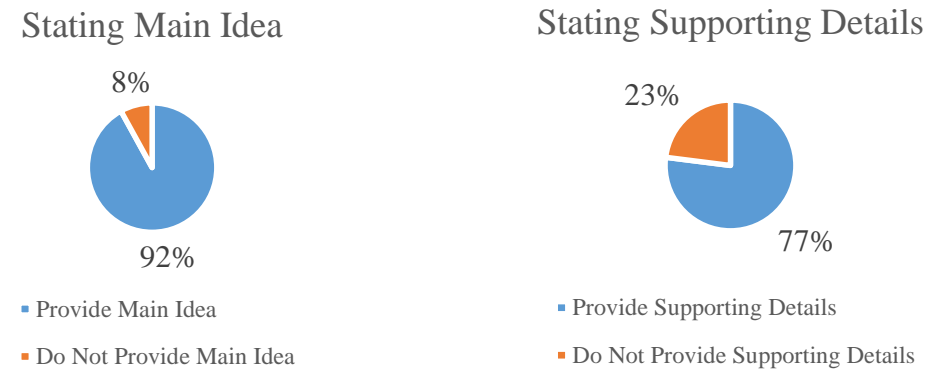

Fig. 4. Student's Meaningful Communication Production

The result in figure 4 showed $92 \%$ of the students were able to provide the main idea and $77 \%$ of the students were able to explain the main idea by providing supporting details. This finding showed that the students were able to express their opinion meaningfully. Hence, the big portion of concern should be more on pronunciation and grammatical errors. The teachinglearning activities in the classroom should be more focus on speaking practice to stimulate the student's speaking skills. Besides, the lecturer also needs to provide immediate constructive feedback when the students have a speaking task to avoid the fossilization in their errors \& mistakes. Besides, more practice also may provide more exposure and input to the students.

\section{CONCLUSION}

From nine factors that were affecting the student's speaking fluency, linguistics factors became the biggest portion to put on the concern while creating the learning materials as well as in delivering the teaching-learning method in English in Focus course. To gain the students' motivation and engagement, the lecturer should provide more meaningful teaching activities that closely related to their life as well as utilize challenging teaching methods, such as gamebased learning, gamification, case study, debate, jigsaw-puzzle, and so on and so forth. Those methods required students' critical thinking as well as active participation from the students. Besides, immediate constructive feedback on students' mispronunciations and grammatical errors were also suggested to be done by the lecturer to avoid and minimize the fossilization. 


\section{ACKNOWLEDGEMENTS}

Acknowledgments. Our thanks to Bina Nusantara University for the research grant that funding this study.

\section{REFERENCE}

[1] D. T. J. Kumar, "Teaching speaking: from fluency to accuracy," J. English Lang. Teach., vol. LV/ 6, no. November 2013, pp. 16-21, 2013.

[2] G. Shahini and F. Shahamirian, "Improving English Speaking Fluency: The Role of Six Factors," Adv. Lang. Lit. Stud., vol. 8, no. 6, p. 100, 2017.

[3] A. Yi, "On the factors influencing L1 transfer," Theory Pract. Lang. Stud., vol. 2, no. 11, pp. 2372-2377, 2012.

[4] M. Senel, "Suggestion for Beautifying the Pronunciation of EFL Learners in Turkey," J. Lang. Linguist. Stud., vol. 2006, no. 1, pp. 7-9, 2006.

[5] S. R. Srivastava, "Accuracy Vs Fluency in English Classroom," New Man Int. J. Multidiscip. Stud., vol. 1, no. 4, pp. 2348-1390, 2014.

[6] Y. I. J. Yang, "The development of speaking fluency: The 4/3/2 technique for the EFL learners in China," Int. J. Res. Stud. Lang. Learn., vol. 3, no. 4, pp. 55-70, 2013. 